\title{
Enhancing the growth performance of replacement female breeder goats through modification of feeding program
}

\author{
A. A. A. Ghani ${ }^{1}$, M. S. Shahudin ${ }^{1}$, M. Zamri-Saad ${ }^{2}$, A. B. Zuki², H. Wahid ${ }^{2}$, A. Kasim³ , M. S. Salisi ${ }^{1}$ and \\ Hasliza Abu Hassim ${ }^{1,2}$
}

\begin{abstract}
1. Department of Veterinary Preclinical Sciences, Faculty of Veterinary Medicine, Universiti Putra Malaysia, 43400 Serdang, Selangor Darul Ehsan, Malaysia; 2. Research Centre for Ruminant Diseases, Faculty of Veterinary Medicine, Universiti Putra Malaysia, 43400 Serdang, Selangor Darul Ehsan, Malaysia; 3. Department of Animal Science, Faculty of Agriculture, Universiti Putra Malaysia, 43400 Serdang, Selangor Darul Ehsan, Malaysia.

Corresponding author: Hasliza Abu Hassim, e-mail: haslizaabu@upm.edu.my,

Co-authors: AAAG: ahmadafifi.vet@gmail.com, MSS: syafeeqshah.vet@gmail.com, MZS: zamri@upm.edu.my,

ABZ: zuki@upm.edu.my, HW: wahidh@upm.edu.my, AK: azharkasim@upm.edu.my, MSS: shahrom@upm.edu.my Received: 28-11-2016, Accepted: 21-04-2017, Published online: 11-06-2017
\end{abstract}

doi: 10.14202/vetworld.2017.630-635 How to cite this article: Ghani AAA, Shahudin MS, Zamri-Saad M, Zuki AB, Wahid H, Kasim A, Salisi MS, Hassim HA (2017) Enhancing the growth performance of replacement female breeder goats through modification of feeding program, Veterinary World, 10(6): 630-635.

\begin{abstract}
Aim: The study was conducted at a smallholder goat farm located in Labu, Negeri Sembilan, Malaysia. The objective of this study was to evaluate the effect of proper feeding program on growth performances of replacement breeder goats.

Materials and Methods: A total of 30 healthy female boer cross goats at the age of 4 months old with average initial live body weight $(\mathrm{BW})$ of $20.05 \pm 0.5 \mathrm{~kg}$ were used for on-farm feeding trial to evaluate the growth performance as preparation for breeding purposes. The experimental goats were divided into two groups of 15 animals each labeled as control and treatment groups, which were kept under intensive farming system. Goats in control group were fed with normal routine feeding protocol practiced by the farmer, while goats in the treatment group were fed with new feed formulation. Throughout the experimental period, on-farm monitoring and data collection were carried out. Initial BW and body condition score (BCS) were recorded before the start of the experiment while final BW and BCS were gained after 7 months of the experimental period. Average daily gain (ADG) was calculated after the experiment end. Data on BW, ADG, and BCS were recorded from both groups for every 2 weeks and reported monthly. The feed intake for the control group was $2.8 \mathrm{~kg} / \mathrm{animal} / \mathrm{day}$ which practiced by the farmer and $3.2 \mathrm{~kg} / \mathrm{animal} /$ day as new feed formulation for the treatment group.
\end{abstract}

Results: After 7 months of the experimental period, final BW shows an improvement in treatment group (39.1 $1.53 \mathrm{~kg})$ compared with control group $(32.3 \pm 1.23 \mathrm{~kg})$. The ADG in treatment group also gives promising result when comparing with control group. Goats in treatment group significantly attained better ADG than control group which were $126.7 \mathrm{~g} / \mathrm{day}$ and $83.3 \mathrm{~g} /$ day, respectively. For the BCS, goats in the treatment group had shown an improvement where 86.67\% (13 out of 15) of the group had BCS $\geq 3$ ( $1-5$ scoring scale) and only $66.67 \%$ (10 out of 15 ) of the control group had BCS $\geq 3$.

Conclusion: Therefore, it was concluded that implementation of proper feeding program as shown in treatment group give promising result to improve the growth performance of replacement breeder goats which can be adopted by the farmers to improve farm productivity.

Keywords: feeding, goat, growth performance, replacement breeder.

\section{Introduction}

Postweaning phase, also known as grower phase, is a critical part where the ability of the farmers to manage this phase will determine the sustainability of the farm, regardless of the production system either for meat or milk. Within this phase, the kids are totally separated from the dam and able to consume solid feed as their rumen fully develop and were raised either as replacement herd or slaughter for meat. Postweaning period can be stressful and critical period resulting in weaning shock [1] and often affect the growth

Copyright: Ghani, et al. Open Access. This article is distributed under the terms of the Creative Commons Attribution 4.0 International License (http://creativecommons.org/licenses/by/4.0/), which permits unrestricted use, distribution, and reproduction in any medium, provided you give appropriate credit to the original author(s) and the source, provide a link to the Creative Commons license, and indicate if changes were made. The Creative Commons Public Domain Dedication waiver (http://creativecommons.org/ publicdomain/zero/1.0/) applies to the data made available in this article, unless otherwise stated. performance by slowing or stoppage of growth and even loss of weight gain [2].

In the aspect of nutritional management, adequate nutrient should be given to animal according to their sex, age, breed, production system (dairy or meat), body size, climate, and physiological stages [3]. It is important to ensure the animal diet is formulated to support optimal production and be economical [4]. For the selected kids to be replacement breeder that kept under intensive farming system, diets or feed must be carefully formulated to assure that all nutrient requirements of the animal are met as the animal have limited choice in selecting the feed. It is well known that deficit or excess of nutrients during growth has a negative effect on the production traits of female at maturity [5].

To be a potential replacement breeder especially female goat, it is important to have a good body condition and growth rate as well as proper weight for 
breeding. Unable to have these criteria may cause it to be rejected or culled from the replacement herd. The slow growth rate is mainly attributed to poor nutrition and management and nongenetic factors, such as season, sex, type of birth, and dam age or parity [6]. To majority of smallholder farmers, balance feeding is less concerned due to time, cost constrain, and labor issues. Indeed, imbalance feeding could affect the physiological function due to inadequate nutrient and further lead to reduction in growth performance and productivity of the farms. Unable to provide sufficient nutrients during postweaning may cause decreased kid growth, delay in puberty, lowered fertility, and lowered resistance to disease and parasites [7].

In Malaysia, most of the smallholder goat farms are not managed properly due to poor knowledge and information in standard management practice for goat farm, which further resulted in poor performance of these goat farms. Indeed, most of smallholder farm has never adopted any standard rearing management, particularly on feeding protocol which further resulted in lower performance of the goats with respect on growth and breeding performance, feed utilization and production. Thus, it is important to implement a proper feeding program to the replacement herd to ensure that the goats are ready and in good body condition for breeding as well as improvement in growth performance with respect to the body weight (BW), average daily gain (ADG), and body condition score (BCS). Therefore, the objective of this study is to evaluate the effect of implementation a proper feeding program on growth performances of replacement breeder goats as compared to the routine feeding program practice by the smallholder farmer under intensive farming system.

\section{Materials and Methods}

\section{Ethical approval}

The experimental protocol used in this study was approved by Institutional Animal Care and Use Committee (IACUC) with reference number UPM/ IACUC/AUP-R039/2016, in accordance with the standard guidelines on usage and care of experimental animals.

\section{Experimental design}

This study was conducted at a goat farm located in Labu, Negeri Sembilan, Malaysia. The total population of goat raised in this farm was considered small $(n=100)$ as this farm was managed by a smallholder farmer. Thus, in this study, 30 healthy female boer cross goats at the age of 4 months old (postweaning) with average initial live BW of $20.05 \pm 0.5 \mathrm{~kg}$ were selected and used for on-farm feeding trial to evaluate the growth performance as preparation for breeding purposes. All goats were kept in the same housing area to reduce biases from environmental factors and were managed under intensive farming system. The goats were then divided equally into control $(n=15)$ and treatment $(n=15)$ groups. Each group was fed with different feed formulations, in which the control group was fed according to the routine feeding program by the farmer. Indeed, after a thorough screening and complete feed analysis was done, this feeding program was found inadequate and failed to meet the requirement in term of quantity and quality of the feed. As for the treatment group, the goats were fed with standard feeding program according to the recommendation by NRC [8]. In this study, both groups were fed with same local feed resources such as Napier grass, local plants which include Macaranga sp. and Mallotus sp., pressed soy waste and commercial concentrate with different proportions (Table-1). All goats were fed twice a day, which consists of pressed soy waste and commercial concentrate mixture in the morning $(900 \mathrm{~h})$ and Napier grass and local plants mixture in the evening $(1700 \mathrm{~h})$.

The feeding trial lasted for 7 months started from postweaning age (4 months old) until the goats reach the breeding criteria, approximately at the age of 11 months old. Throughout the experimental period, on-farm monitoring and data collection were carried out. Clean water was supplied ad-libitum during the feeding trial and anti-stress (Stress Pack $^{\circledR}$ ) was provided in drinking water every 2 weeks to reduce stress to the animals. Three parameters associated with growth performance were determined in this study which consists of BW, ADG, and BCS as described by Salisi [9].

\section{Feed analysis}

Before the implementation of feeding trial was conducted, the nutrient composition (dry matter, crude protein, crude fiber, crude fat) for total mix ration of the feed given to the goats for each diet groups (control and treatment groups) were determined by proximate analysis. Proximate analysis is the most common analysis performed on feed samples, where it consists of a series of analyses to estimate the nutrient characteristic of feeds which includes the following: Dry matter, crude protein, crude fat, and crude fiber. All the analyses were performed according to certified procedures outlined by the Manual of Laboratory Techniques, Universiti Putra Malaysia which was developed according to procedures of AOAC [10]. The proximate analysis of the samples was performed in 4 replicates.

Table-1: Feed formulation for control and treatment groups.

\begin{tabular}{lcc}
\hline Feed ingredients & Control group & Treatment group \\
\hline Napier grass $(\mathrm{kg})$ & 1.2 & 1.2 \\
Mallotus sp. $(\mathrm{kg})$ & 0.4 & 0.4 \\
Macaranga sp. $(\mathrm{kg})$ & 0.4 & 0.4 \\
Pressed soy & 0.72 & 0.95 \\
waste $(\mathrm{kg})$ & 0.08 & 0.25 \\
Commercial & & \\
concentrate $(\mathrm{kg})$ & & \\
Total feed given & $2.8 \mathrm{~kg}$ animal/day & $3.2 \mathrm{~kg} /$ animal/day \\
\hline
\end{tabular}




\section{Measurement of BW and ADG}

Initial BWs of the experimental animals were taken at the beginning of the study by two consecutive weighing in the morning before feeding. Live weight gain of each animal was recorded at 14 days interval, at $800 \mathrm{~h}$ in the morning before feeding and reported monthly until at the end of 7 months of feeding trial period. ADG was calculated as the difference between final live weight and initial live weight divided by the number of days of the feeding trial. In this study, ADG was calculated for every 30 days.

\section{Measurement of BCS}

BCS was measured using a scale of $1-5$ as described by Koyuncu [11]. Determination of the scoring was made by several characteristics of the goats as stated in Table- 2 .

\section{Data analysis}

Data from feeding trial (monthly BW, ADG, and BCS) for both groups were recorded for further analysis. Preliminary data analysis such as normality test and screening for outliers were performed before conducting the main data analysis. Data of BW and ADG from every month then were entered into SPSS software for t-test analysis at $\mathrm{p}<0.05$ while the percentage of BCS were calculated using Microsoft Excel software.

\section{Results}

\section{Proximate analysis}

The result of proximate analysis for all feed formulation (control and treatment groups) was tabulated in Table-3.

From Table-3, dry matter content in both feed formulation does not show a significant difference. As expected, crude protein, crude fiber, and crude fat content in treatment group were higher than control group and shown significant difference between both groups.

BW

The first parameter to assess growth performance is BW. For the results of BW, at the beginning of experiment before feeding trial, the mean of initial BW in control and treatment groups almost similar which are $20.0 \pm 0.52 \mathrm{~kg}$ and $20.8 \pm 0.71 \mathrm{~kg}$, respectively. Then, after 7 months of feeding trial, the mean of final BW in treatment group $(39.1 \pm 1.53 \mathrm{~kg})$ shown a significant improvement compared with control group $(32.3 \pm 1.23 \mathrm{~kg})$. BW gain in 7 months for control and treatment group was $12.3 \mathrm{~kg}$ and $18.3 \mathrm{~kg}$, respectively. The monthly progressions were tabulated in Table- 4 and expressed in kilogram.

\section{ADG}

The second parameter to assess growth performance is ADG. ADG is a reflection from the increment of the BW in a period of time. In this study, ADG was calculated every month for each animal until the end of the experimental period. After 7 month, ADG in treatment group give promising results compared
Table-2: Body condition score scale.

\begin{tabular}{|c|c|}
\hline Scale & Descriptions \\
\hline $\begin{array}{l}1 \text { (very thin or } \\
\text { emaciated) }\end{array}$ & $\begin{array}{l}\text { Spinous processes are sharp and } \\
\text { prominent. Transverse processes are } \\
\text { sharp. No fat cover }\end{array}$ \\
\hline 2 (thin) & $\begin{array}{l}\text { Spinous processes are less sharp and } \\
\text { prominent. Transverse processes are } \\
\text { sharp. Less fat cover }\end{array}$ \\
\hline $\begin{array}{l}3 \text { (medium or } \\
\text { moderately lean) }\end{array}$ & $\begin{array}{l}\text { Spinous processes are smooth and } \\
\text { rounded. Transverse processes are } \\
\text { smooth and well covered. Some fat } \\
\text { cover. Ideal body condition score }\end{array}$ \\
\hline 4 (moderately fat) & $\begin{array}{l}\text { Spinous and transverse processes } \\
\text { well covered and rounded. Thick } \\
\text { muscle }\end{array}$ \\
\hline 5 (very fat/obese) & $\begin{array}{l}\text { Spinous processes cannot be } \\
\text { detected. Muscle is very full with very } \\
\text { thick fat cover }\end{array}$ \\
\hline
\end{tabular}

Table-3: Nutrient composition of feed formulation in control and treatment groups.

\begin{tabular}{lcc}
\hline \multirow{2}{*}{$\begin{array}{l}\text { Nutrient } \\
\text { composition (\%) }\end{array}$} & \multicolumn{2}{c}{ Mean \pm SEM } \\
\cline { 2 - 3 } & Control group & Treatment group \\
\hline Dry matter & $71.45 \pm 1.27^{\mathrm{a}}$ & $72.58 \pm 0.82^{\mathrm{a}}$ \\
Crude protein & $11.39 \pm 0.74^{\mathrm{a}}$ & $16.04 \pm 0.61^{\mathrm{b}}$ \\
Crude fiber & $20.44 \pm 0.35^{\mathrm{a}}$ & $23.82 \pm 0.54^{\mathrm{b}}$ \\
Crude fat & $2.21 \pm 0.24^{\mathrm{a}}$ & $3.08 \pm 0.33^{\mathrm{b}}$ \\
\hline
\end{tabular}

$a, b$ Different alphabets within a row indicate significant difference between means using t-test at $p<0.05$. SEM $=$ Standard error of the mean

with the control group. In the $1^{\text {st }}$ month of feeding trial, the mean of ADG for control and treatment groups were $36.7 \mathrm{~g} /$ day and $53.3 \mathrm{~g} /$ day, respectively. Then, after 7 month of feeding trial, the mean of ADG for control and treatment groups were $83.3 \mathrm{~g} /$ day and $126.7 \mathrm{~g} /$ day, respectively. The difference of ADG between control and treatment groups was increased from $16.6 \mathrm{~g} /$ day in the $1^{\text {st }}$ month to $43.4 \mathrm{~g} /$ day in the $7^{\text {th }}$ month of feeding trial. The monthly results of ADG were summarized in Table-5 and expressed in $\mathrm{g} /$ day.

BCS

The third parameter to assess growth performance is BCS. BCS system uses a scale from 1 (very thin) to 5 (very fat). At the beginning of this study, both groups have an equal percentage of animals that having $\mathrm{BCS} \geq 3$ which is $40.0 \%$ while the remaining having BCS $<3$. After 7 months of feeding trial, the percentage of $\mathrm{BCS} \geq 3$ in control and treatment groups was $60.0 \%$ and $86.7 \%$, respectively. The monthly progressions were tabulated in Table- 6 .

\section{Discussion}

During postweaning or grower stage, providing adequate nutrients through proper feeding program is very important especially to the replacement herd as preparation for breeding purpose. Nutrients composition of feedstuffs and feed intake by the animal should be considered during formulating the total mix ration. Within this stage, energy and protein are the greater nutrients need by the young goats to build new tissues 
Table-4: The measurement of body weight in control and treatment groups throughout feeding trial.

\begin{tabular}{llcr}
\hline Age of animal & Duration of feeding trial & \multicolumn{2}{c}{ Mean \pm SEM } \\
\cline { 3 - 4 } & & Control group $(\mathbf{n = 1 5})$ & Treatment group $(\mathbf{n = 1 5})$ \\
\hline 4 months old & Initial body weight & $20.0 \pm 0.52^{\mathrm{a}}$ & $20.8 \pm 0.71^{\mathrm{a}}$ \\
5 months old & 1 month & $21.1 \pm 0.48^{\mathrm{a}}$ & $22.4 \pm 0.64^{\mathrm{a}}$ \\
6 months old & 2 months & $22.4 \pm 0.35^{\mathrm{a}}$ & $24.2 \pm 0.51^{\mathrm{a}}$ \\
7 months old & 3 months & $23.9 \pm 0.54^{\mathrm{a}}$ & $26.3 \pm 0.45^{\mathrm{b}}$ \\
8 months old & 4 months & $25.6 \pm 0.81^{\mathrm{a}}$ & $28.8 \pm 0.87^{\mathrm{b}}$ \\
9 months old & 5 months & $27.6 \pm 1.13^{\mathrm{a}}$ & $31.8 \pm 1.21^{\mathrm{b}}$ \\
10 months old & 6 months & $29.8 \pm 1.33^{\mathrm{a}}$ & $35.3 \pm 1.18^{\mathrm{b}}$ \\
11 months old & 7 months & $32.3 \pm 1.23^{\mathrm{a}}$ & $39.1 \pm 1.53^{\mathrm{b}}$ \\
\hline
\end{tabular}

a,bDifferent alphabets within a row indicate significant difference between means using t-test at $p<0.05$. SEM $=\mathrm{Standard}$ error of the mean

Table-5: The measurement of average daily gain in control and treatment groups throughout feeding trial.

\begin{tabular}{llcr}
\hline Age of animal & Duration of feeding trial & \multicolumn{2}{c}{ Mean \pm SEM } \\
\cline { 3 - 4 } & & Control group $(\mathbf{n = 1 5})$ & Treatment group $(\mathbf{n = 1 5})$ \\
\hline 5 months old & 1 month & $36.7 \pm 2.11^{\mathrm{a}}$ & $53.3 \pm 3.25^{\mathrm{b}}$ \\
6 months old & 2 months & $43.3 \pm 2.53^{\mathrm{a}}$ & $60.0 \pm 3.46^{\mathrm{b}}$ \\
7 months old & 3 months & $50.0 \pm 3.22^{\mathrm{a}}$ & $70.0 \pm 3.73^{\mathrm{b}}$ \\
8 months old & 4 months & $56.7 \pm 3.51^{\mathrm{a}}$ & $83.3 \pm 4.13^{\mathrm{b}}$ \\
9 months old & 5 months & $66.7 \pm 2.98^{\mathrm{a}}$ & $100.0 \pm 4.55^{\mathrm{b}}$ \\
10 months old & 6 months & $73.3 \pm 3.34^{\mathrm{a}}$ & $116.7 \pm 4.28^{\mathrm{b}}$ \\
11 months old & 7 months & $83.3 \pm 4.07^{\mathrm{a}}$ & $126.7 \pm 5.16^{\mathrm{b}}$ \\
\hline
\end{tabular}

a,bDifferent alphabets within a row indicate significant difference between means using t-test at $p<0.05$. SEM $=S$ tandard error of the mean

Table-6: The measurement of body condition score in control and treatment groups throughout feeding trial.

\begin{tabular}{|c|c|c|c|c|}
\hline \multirow[t]{2}{*}{ Duration of feeding trial } & \multicolumn{2}{|c|}{ Control group $(n=15)$} & \multicolumn{2}{|c|}{ Treatment group $(n=15)$} \\
\hline & BCS $<3(\%)$ & $\mathrm{BCS} \geq 3(\%)$ & BCS $<3(\%)$ & $B C S \geq 3(\%)$ \\
\hline Beginning & $9(60.0)$ & $6(40.0)$ & $9(60)$ & $6(40)$ \\
\hline 1 month & $8(53.3)$ & $7(46.7)$ & $7(46.7)$ & $8(53.3)$ \\
\hline 2 months & $8(53.3)$ & $7(46.7)$ & $6(40.0)$ & $9(60.0)$ \\
\hline 3 months & $7(46.7)$ & $8(53.3)$ & $5(33.3)$ & $10(66.7)$ \\
\hline 4 months & $7(46.7)$ & $8(53.3)$ & $3(20.0)$ & $12(80.0)$ \\
\hline 5 months & $6(40.0)$ & $9(60.0)$ & $3(20.0)$ & $12(80.0)$ \\
\hline 6 months & $6(40.0)$ & $9(60.0)$ & $2(13.3)$ & $13(86.7)$ \\
\hline 7 months & $6(40.0)$ & $9(60.0)$ & $2(13.3)$ & $13(86.7)$ \\
\hline
\end{tabular}

$\mathrm{BCS}=$ Body condition score

for growth or replacement in an animal body [12]. In this study, the feed ingredients used are similar for both groups except the proportion of pressed soy waste and commercial concentrate which are different. Additional $230 \mathrm{~g}$ of pressed soy waste and $170 \mathrm{~g}$ of commercial concentrate were included in treatment group as protein and energy source, respectively. As animal grows from 6 months to breeding age, they may require at least $14-16 \%$ protein. Feeding more than $25 \%$ is not recommended for rapidly growing replacement animals [13].

On the aspect of $\mathrm{BW}$, proper feeding program should be able to improve BW to gain desired BW for breeding. The proper time of breeding depends on the weight and age of the doe. Proper weight for breeding in does usually when the animal attained $60-70 \%$ of its mature BW. According to Grayling [14], recommended BW at first estrus for boer female goats is $31.3 \mathrm{~kg}$. Thus, in this study, it revealed that goats from treatment group reach the minimum BW for breeding with weight of $31.8 \pm 1.21 \mathrm{~kg}$ at the age 9 months old while goats from control group reach the minimum BW for breeding with weight of $32.3 \pm 1.23 \mathrm{~kg}$ at the age 11 months old. It shown those goats in treatment group can be bred 2 months earlier than goats in control group. This supported by Jaudas and Mobini [15] where the study stated that a normally developed young doe can be bred at the age of about 9 months old without problem and will kid for the first time at the age of 14 months. Furthermore, feed formulation given to the goats in treatment group give promising improvement to $\mathrm{BW}$ gain compared with control group.

BCS is one of the growth performance parameters used in the evaluation and management of goat herd [16]. BCS can be defined as the level of fatness or thinness of the animal. BCS system uses a scale from 1 (very thin) to 5 (very fat). Within grower stage, 
monitoring on BCS very important to determine feed convertibility, health status, ability to gain, and establishing the condition of animal during routine management as well as related to fertility in breeding animals. As for breeding preparation, replacement doe should be raised under conditioning process which means to gain desired ideal body condition and BW. The recommended ideal BCS for breeding is 3-3.5 [17]. Goats that having poor $\mathrm{BCS}(<3)$ should receive flushing to reach ideal score while goats are too fat (BCS more than 4) should be fed with low energy feed to reduce $\mathrm{BCS}$ to ideal range. In addition, does in greater BCS having high ovulation rate which will increase the chances to get pregnant compared with does in poor BCS $[18,19]$. Replacement goats that are supplemented with high energy and protein before breeding have greater body condition subsequently leads to normal estrous cycles and increase the ovulation rate. Female goats with poor body condition have abnormal estrous cycles and fewer ovulations than female goats in greater body condition [20]. In this study, it revealed goats in treatment group that had BCS $\geq 3$ increased significantly from $40.0 \%$ at the beginning to $86.7 \%$ after 7 months of feeding trial and ready to be bred support by meeting the desired BW for breeding. Meanwhile, in control group, only $60.0 \%$ of the goats had BCS $\geq 3$ after 7 months of feeding trial and ready to be bred. BCS also can be used to evaluate the health status of the animals. For example, sick goats that suffering from gastrointestinal parasitism had poor BCS with other clinical signs such as scouring, unthriftiness, weight lost, reduce weight gain, and reproductive inefficiency [21].

\section{Conclusion}

After 7 months of feeding trial, all parameters for assessing the growth performance of animals in treatment group had shown the promising result when compared with control group. It is extremely important to meet the goat's requirement by providing and implementing a proper feeding program to improve the performance of replacement goats, especially growth performance as well as to increase the productivity of the farm.

\section{Authors' Contributions}

All authors were involved and contributed in this research works. AAAG, HAH, MSS, MZS, ABZ, HW, $\mathrm{AK}$ and MSS were involved in experimental trial and data collection. AAAG and HAH wrote and edited the manuscript according to the title. All authors read and approved the final manuscript.

\section{Acknowledgments}

The authors acknowledge the financial support from Ministry of Higher Education (MOHE) and Economic Planning Unit (EPU), under Knowledge Transfer Program (KTP) grant (reference number: I-ECO/5 (UPM-14-2)). We would express our sincere thanks to individuals and institutions for the support either directly or indirectly in completion of this project.

\section{Competing Interests}

The authors declare that they have no competing interests.

\section{References}

1. Lynch, E.M., Earley, B., McGee, M. and Doyle, S. (2010) Effect of abrupt weaning at housing on leukocyte distribution, functional activity of neutrophils, and acute phase protein response of beef calves. BMC Vet. Res., 6: 39-47.

2. Memiši, N., Žujović, M., Tomić, Z. and Petrović, M.P. (2009) The effect of time of weaning on body mass and gain of kids. Biotechnol. Anim. Husbandry, 25(5-6): 993-998.

3. Rashid, M. (2008) Goats and their Nutrition. Available from: https://www.gov.mb.ca/agriculture/livestock/production/goat/pubs/goat-and-their-nutrition.pdf. Retrieved on 17-09-2016.

4. Martínez-Marín, A.L., Pérez-Hernández, M., PérezAlba, L.M., Carrión-Pardo, D. and Gómez-Castro, A.G. (2012) Nutrient limits in diets for growing dairy goats. Arch. Med. Vet., 44: 13-20.

5. Komala, T.S., Mahadi, Y., Khairunnisak, M. and Ramlan, M. (2011) Studies on nutritionally related blood metabolites - Total protein and glucose level in goat of Kinta and Hilir Perak district. Malays. J. Vet. Res., 2(2): 9-16.

6. Gbangboche, A.B., Adamou-Ndiaye, M., Youssa, A.K.I., Farnir, F., Detilleux, J., Abiola, F.A. and Leroy, P.L. (2006) Non-genetic factors affecting the reproduction performance, lamb growth and productivity indices of Djallonke sheep. Small Rumin. Res., 64(1): 133-142.

7. McMillin, K.W. (2010) Meat production and quality. In: Solaiman, S.G., editor. Goat Science and Production. $1^{\text {st }}$ ed. Wiley-Blackwell, United States. p259-261.

8. NRC. (2007) Nutrient Requirement of Small Ruminants: Sheep, Goats, Cervids, and New World Camelids. $6^{\text {th }}$ ed. National Academy Press, Washington DC, USA.

9. Salisi, M.S. (2011) Effects of Implementing Feeding, Breeding and a Herd Health Program on the Performance of Boer Goat Breeding Farm in Sabah. PhD Thesis, University Putra Malaysia.

10. AOAC. (2000) Association of official analytical chemists. Official Methods of Analysis. $6^{\text {th }}$ ed. AOAC, Washington, DC, USA.

11. Koyuncu, M. (2013) Importance of body condition score in dairy goats. Maced. J. Anim. Sci., 3: 167-173.

12. Mowlem, A. (1992) Goat Farming. $2^{\text {nd }}$ ed. Crowood Press, US. p40-41.

13. Solaiman, S.G., editor. (2010) Feed and feeding management. In: Goat Science and Production. $1^{\text {st }}$ ed. WileyBlackwell, USA. p205-206.

14. Greyling, J. (2010) Applied reproductive physiology. In: Solaiman, S.G., editor. Goat Science and Production. $1^{\text {st }}$ ed. Wiley-Blackwell, Ames, IA. p139-141

15. Jaudas, U. and Mobini, S. (2006) Breeding and raising young. In: Jaudas, U., Mobini, S., editors. The Goat Handbook. $1^{\text {st }}$ ed. Barron's, New York. p89.

16. Ebert, R.A. and Solaiman, S.G., editors. (2010) Animal evaluation. Goat Science and Production. $1^{\text {st }}$ ed. WileyBlackwell, Langston, OK. p85.

17. Villaquirán, M., Gipson, R., Merkel, R., Goetsch, A. and Sahlu, T. (2012) Body Condition Scores in Goats. Langston University, Agriculture Research and Cooperative Extension. Langston, Oklahoma, US. Available from: http:// www.ans.iastate.edu/faculty/morrical/acc/GoatResearch. pdf. Retrieved on 15-08-2016.

18. Forcada, F., Abecia, J.A. and Sierra, I. (1992) Seasonal changes in oestrus activity and ovulation rate in rasa 
aragonesa ewes maintained at two different body condition levels. Small Rumin. Res., 8: 313-324.

19. Meza-Herrera, C.A., Hallford, D.M., Ortiz, J.A., Cuveas, R.A., Sanchez, J.M., Salinaz, H., Mellado, M. and Gonzalez-Bulnes, A. (2008) Body condition and protein supplementation positively affect periovulatory ovarian activity by non LH-mediated pathways in goats. Anim. Reprod. Sci., 106: 412-420.
20. De Santiago-Miramontes, M.A., Malpaux, B. and Delgadillo, J.A. (2009) Body condition is associated with a shorter breeding season and reduced ovulation rate in subtropical goats. Anim. Reprod. Sci., 114: 175-182.

21. Miller, J.E., Olcott, B.M. and Bath, G.F. (2010) Health management, diseases and parasites. In: Solaiman, S.G., editor. Goat Science and Production. $1^{\text {st }}$ ed. Wiley-Blackwell, Ames, IA. p229-231.

$* * * * * * * *$ 